\title{
ANTIMICROBIAL SUSCEPTIBILITY TO SALMONELLA AND E.COLI ISOLATES ORIGINATED FROM BROILER CHICKENS IN LUXOR GOVERNORATE
}

\author{
SAFAA ZAKARIA ${ }^{1}$; AHMED I. AHMED ${ }^{2}$; NABILA OSMAN ${ }^{2}$ and SOAD A. NASEF ${ }^{3}$ \\ ${ }^{1}$ Reference Laboratory for Veterinary Quality Control on Poultry Production (RLQP), Animal Health Institute, Luxor, Egypt \\ ${ }^{2}$ Department of Poultry and Rabbit Diseases, Faculty of Veterinary Medicine, South Valley University, Qena, Egypt \\ ${ }^{3}$ National Laboratory for Veterinary Quality Control on Poultry Production (NLQP), Animal Health Institute, Dokki, Giza, \\ Egypt
}

Received: 31 March 2018; Accepted: 31 April 2018

\begin{abstract}
Salmonellosis and colibacillosis are continuing serious problems facing poultry industry in Egypt. In this study, 300 different pooled broiler chickens organs samples as (trachea, lung, liver, heart, spleen, unabsorbed yolk sac and intestine) were collected from different apparently healthy and sick broiler flocks in different localities of Luxor governorate during (2015 and 2016). The examined broiler flocks were suffering from various health problems developed during the final two weeks of the growing period, resulting in increased mortality and condemnation losses. Bacterial isolation was done by using standard method of isolation and identification. The results showed that 92 out of 300 broiler organs samples were positive for Salmonella spp. (30.66\%) while 161 out of 300 were E.coli positive (53.66\%). The present study showed that the main Salmonella spp. isolates were ( $S$. Typhimurium (24\%), the both of $S$. Enteritidis, $S$. Anatum were (21.7\%) and $S$. Kentucky (19.56\%), $S$. Bargny and $S$. Molade (3.26\%) then $S$. Newport, S. Ingada and S. Agona their percentage were $(2.17 \%)$ respectively, while 8 serotypes of E.coli were obtained with the following serological identification $\mathrm{O} 78(44 \%)$, O1:H7 (17.39\%), O91:H21 (15.52\%), O128:H2 (13\%) and other E.coli serotypes were identified as (O2:H6, $\mathrm{O} 26: \mathrm{H} 11$, O55:H7, O146:H21) their percentage was (1:3\%). Bacterial strains were tested against 21 antibacterial agents using the standard disk diffusion method on Muller and Hinton's Agar medium. The results were recorded that most of Salmonella spp were highly resistant to (Oxytetracycline, Doxycycline, Tetracycline then Enrofloxacin, Sulphamethoxazole) and were sensitive to (Gentamycin, colistinsulphate and Ceftiofur). While most of E.coli isolates were resistant to Neomycin and Streptomycin and were sensitive to Ceftiofur then Colistinsulphate.
\end{abstract}

Key Words: Broilers, Salmonella, E.Coli, Infection, Serotyping multi antibiotic resistant.

\section{INTRODUCTION}

Avian pathogenic Escherichia coli (APEC) is the major cause of Colibacillosis in poultry (SolàGinés et al., 2012). It is a common world wide disease in poultry flocks especially in the intensive farming system (Chansiripornchai., 2009) and Gamal et al., (2017) examined 200 broiler chickens and found $73(36.5 \%)$ were infected with E.coli, strains $(\mathrm{O} 78, \mathrm{O} 2$, and $\mathrm{O} 1)$ are the most prevalent serotypes detected. It affects birds of all ages, spread into various internal organs and cause Colibacillosis characterized by systemic fatal disease (De Carli et al., 2015). Clinically E. coli infected birds revealed sudden death to birds being off-color with their necks pulled into their bodies (Johnston., 2007). On the other hand, Salmonella infection caused by avariety

Corresponding author: Dr. SAFAA ZAKARIA

E-mail address: $\underline{\text { _z } z 11 @ y a h o o . c o m ~}$

Present address: Reference Laboratory for Veterinary Quality Control on Poultry Production (RLQP), Animal Health Institute, Luxor, Egypt of Salmonella species is one of the most important bacterial diseases in poultry causing heavy economic losses through mortality and reduced production (Haider et al., 2004). Salmonellosis is associated with massive public health and economic losses globally. It is estimated to cost poultry farmers in the United States of America up to US\$ 114 million annually. Attempts to develop effective vaccines and eradicate Salmonella entericaserovar Enteritidis ( $S$. Enteritidis) from henhouses are undermined by serious limitations (Charles and Takayuki., 2010). The genus Salmonella, a member of the family Enterobacteriaceae, is a facultative intracellular pathogen that is capable of causing different disease syndromes in a wide range of hosts. To date, more than 2,541 serovars of Salmonella have been described (National Salmonella Reference Laboratory, Galway, Ireland), with new serovars being identified every year. Salmonella Typhimurium and Salmonella Enteritidis are the most frequently isolated serovars throughout the world, leading to severe economic losses (Brenner et al., 2000). 


\section{$>\quad$ The aims of the present study were: \\ i. Isolation and Identification of Salmonella, $E$. coli causing losses in broiler farms at Luxor Governorate.}

ii. Performing of Antibiotic sensitivity test.

\section{MATERIALS AND METHODS}

\section{Fieldsamples}

Three hundred $(n=300)$ different pooled broiler chickens organs samples as (trachea, lung, liver, heart, spleen, unabsorbed yolk sac and intestine) were collected as 5 chickens collected their organs as one pooled sample from hundred commercial broiler flocks (1-5 weeks of age) in different localities of Luxor Governorate during the period (January 2015 to December 2016) suspected of having Salmonellosis and Colibacillosis. Clinically a variable number of sick broilers showed (anorexia, difficult respiration, brownish diarrhea, dehydration, weakness, chalky pasty vent, lameness) and post mortem examination was performed on infected and freshly dead birds which succumbed to the diseases after onset of mortalities on the examined farm, gross lesions were recorded from birds with Colibacillosis and Salmonellosis as (septicemia, airsacculitis, polyserositis, inflammation of the intestinal mucosa, necrotic foci on liver or congested liver, kidney and lung, peritonitis, perihepatitis, yolk sac infection, typhilitis, pneumonia, and enteritis). The fresh pooled organs samples (about 25g) were collected aseptically and samples were labeled and placed in sterile containers for bacteriological examination as soon aspossible.

\section{Bacterialisolation}

2.1. Isolation and identification of Salmonella:

- All the collected samples were processed for Salmonella isolation according to (Ahmed et al., 2016) by ISO/IEC 6579/2002 /cor.1:2004.

\subsection{Isolation and identification of $E$. coli isolates:}

- All the samples were processed for E.coli isolation according to (Quinn et al., 2002) by Laboratory manual for isolation and identification of avian pathogen 1998/Amed 2008.

- Biochemical identification for isolated bacteria was done according to (Holmes et al., 1978) by using Api 20E system.

\section{Serologicaltest}

Serotyping of each isolate was done at Reference Laboratory for Veterinary Quality Control on Poultry production (RLQP), Animal Health Institute, Luxor, Egypt. according to Kauffman - White scheme (Kauffman., 1974) for Salmonella by determination of Somatic (O) and flagellar (H) antigensusing
Salmonella antiserum and Kok et al. (1996) for E.coli serological identification by using rapid diagnostic E.coli antisera sets (DENKA SEIKEN Co., Japan) for diagnosis of the Enteropathogenic types.

\section{Sensitivity test}

Salmonella and E. coli isolates were tested for their antimicrobial resistance/susceptibility pattern by disc diffusion technique according to Clinical and Laboratory Standards Institute (CLSI., 2008). This test was done by using Kirby-Bauer disk diffusion test through using 21 antibiotics as Penicillin $\mathrm{G}(\mathrm{P}$ 10ug), Ampicillin (Am 10ug), Amoxicillin (Ax 25ug), Oxacillin (Ox 1ug), Nitrofurantoin (F 300ug), Chloramphenicol (C 30ug), Colistinsulphate (Ct 10ug), Sulphamethoxazole (Sxt 25ug), Flumeqine (Ub 30ug), Enrofloxacin (Enr 5ug), Norfloxacin (Nor 10ug), Ceftiofur (Cf), Levofloxacin (Levo), Ofloxacin (Ofx), Neomycin (N 30ug), Gentamycin (Cn 10ug), Lincomycin (L 2mcg), Streptomycin (S 10ug), Doxycycline (Do $30 \mathrm{ug}$ ), Tetracycline (T 30ug), Oxytetracycline (Ot $30 \mathrm{ug}$ ) and Antibiotic resistance were determined by comparison of the diameter of the zones of complete inhibition with the zone size interpretation chart provided by the supplier and was graded as susceptible (S), intermediate (I), and resistant (R).

\section{RESULTS}

- The result showed that among 300 pooled broiler organs samples, 92 (30.66\%), and 161 (53.66\%) were positive for Salmonella and E.coli isolation respectively (Table :1), also the result expressed that among 300 pooled broiler organs samples, the bacterial isolates from broilers including 9 Salmonella and 8 E.coli serogroups were identified serologically (Table:2,3)

Serological identification of the Salmonella spp isolates were revealed $S$. Typhimurium (24\%), $S$. Enteritidis and $S$. Anatum were (21.7\%), $S$. Kentukey $(19.56 \%), S$. Bargny and $S$. Molade $(3.26 \%)$ then $S$. Newport, $S$. Ingada and $S$. Agona their percentage were $(2.17 \%)$ respectively, while the results showed 8 strains of E.coli were O78 (44\%), O1:H7(17.39\%), O91:H21(15.52\%), O128:H2 (13\%) and other E. coli serogroups (O2:H6, O26:H11, O55:H7,O146:H21) were obtained with percentage varies from $(1: 3 \%)$ (Fig 1, 2).

- The result of sensitivity test revealed that most of Salmonella spp were highly resistant to Oxytetracycline, Doxycycline, Tetracycline then Enrofloxacin, Sulphamethoxazole and were sensitive to Gentamycin, Colistinsulphate and Ceftiofur. While most of $E$. coli isolates were resistant to Neomycin and Streptomycin and were sensitive to Ceftiofur then Colistinsulphate (Table 4,5). 
Table 1: Shows number and percentage of bacterial isolation of broilers.

\begin{tabular}{cccc}
\hline $\begin{array}{c}\text { Samples number and } \\
\text { \% of bacteriaisolates }\end{array}$ & \multicolumn{2}{c}{ Chickens spp (2015, 2016) years } \\
\cline { 2 - 4 } & $\begin{array}{c}\text { Cup, Ross, Hubbard } \\
\text { Chicken }\end{array}$ & $\begin{array}{c}\text { Sasso } \\
\text { Chicken }\end{array}$ & Spp of Chicken \\
\hline Total No of samples & 200 & 100 & 300 \\
\hline No. Positive samples for Salmonella & 50 & 42 & $30.66 \%$ \\
\hline \% of Salmonella Isolates & $25 \%$ & $42 \%$ & 161 \\
\hline No. Positive samples for $E$. coli & 123 & 38 & $53.66 \%$ \\
\hline
\end{tabular}

Table 2: Serological identification of E.coli.

\begin{tabular}{cccccc}
\hline Serial No. & $\begin{array}{c}\text { Identified } \\
\text { bacterium }\end{array}$ & $\begin{array}{c}\text { Serological } \\
\text { diagnosis }\end{array}$ & Serial No. & $\begin{array}{c}\text { Identified } \\
\text { bacterium }\end{array}$ & Serological diagnosis \\
\hline 1 & $E$. coli & O1: H7 & 5 & E. coli & O78 \\
\hline 2 & $E . c o l i$ & $02:$ H6 & 6 & E. coli & O91: H21 \\
\hline 3 & $E . c o l i$ & O26: H11 & 7 & E. coli & O128:H2 \\
\hline 4 & $E . c o l i$ & $055: H 7$ & 8 & $E$. coli & O146: H21 \\
\hline
\end{tabular}

Table 3: Serological typing of isolated Salmonella.

\begin{tabular}{|c|c|c|c|c|}
\hline \multirow[t]{2}{*}{ Serial No. } & \multirow[t]{2}{*}{ Identified strains } & \multirow[t]{2}{*}{ Group } & \multicolumn{2}{|c|}{ Antigenic structure } \\
\hline & & & $\mathbf{O}$ & $\mathbf{H}$ \\
\hline 1 & S. Typhimurium & B & $1,4,5,12$ & i : 1,2 \\
\hline 2 & $S$. Inganda & C1 & 6,7 & $\mathrm{Z10}: \mathbf{1 , 5}$ \\
\hline 3 & S. Kentucky & C3 & 8,20 & i : Z6 \\
\hline 4 & $S$. Enteritidis & D1 & $1,9,12$ & $\mathbf{g , m}$ \\
\hline 5 & S. Bargny & $\mathbf{C 3}$ & 8,20 & i : $\mathbf{1 , 5}$ \\
\hline 6 & S. Molade & $\mathrm{C2}$ & 8,20 & $\mathrm{Z10}: \mathrm{Z6}$ \\
\hline 7 & S. Anatum & $\mathbf{E 1}$ & 3,10 & e,h;1,2 \\
\hline 8 & $S$. Newport & $\mathrm{C2}$ & 6,8 & e,h;1,2 \\
\hline 9 & S. Agona & $\mathbf{B}$ & $1,4(5) ; 12$ & $\mathbf{f , g , s ; ( 1 , 2 )}$ \\
\hline
\end{tabular}


Table 4: Result of sensitivity test for Salmonella spp.

\begin{tabular}{|c|c|c|c|c|}
\hline \multicolumn{5}{|c|}{ *Antibiotics } \\
\hline $\begin{array}{l}\text { Salmonella } \\
\text { isolates }\end{array}$ & $\mathbf{S}$ & \multicolumn{2}{|l|}{ I } & $\mathbf{R}$ \\
\hline S. Typhimurium & Cn, N, F, Ct, Levo, Cf, & Ofx & \multicolumn{2}{|c|}{$\begin{array}{c}\text { Do, Ot, T, L, S, Ax, P, Am, Ox, Ub, } \\
\text { Nor, Enr, C, Sxt }\end{array}$} \\
\hline$S$. Enteritidis & $\begin{array}{l}\text { Cn, N, Do, Ot, T, P, Am, Ax, } \\
\text { Ub, Enr, Nor, Ct, C, Levo, Cf }\end{array}$ & $\mathbf{S}, \mathbf{F}, \mathbf{O f x}$ & \multicolumn{2}{|c|}{$\mathbf{L}, \mathbf{O x}, \mathbf{S x t}$} \\
\hline S. Bargny & $\mathrm{Cn}, \mathrm{L}, \mathrm{F}, \mathrm{Ct}, \mathrm{Cf}, \mathrm{Ofx}$ & $\mathbf{N}$ & \multicolumn{2}{|c|}{$\begin{array}{c}\text { Do, Ot, T, S, P, Am, Ax, Ox, F, Ub, } \\
\text { Nor , Enr, C, Sxt, Levo }\end{array}$} \\
\hline$S$. Kentucky & $\mathrm{Cn}, \mathrm{Ct}, \mathrm{Cf}, \mathrm{Ofx}$ & -- & \multicolumn{2}{|c|}{$\begin{array}{c}\text { Do, Ot, T, L, N, S, Am, Ax, Ox, F, } \\
\text { Ub, Nor, Enr, C, Sxt, P }\end{array}$} \\
\hline S. Inganda & n, Ub, Enr, Nor, Sxt, Ofx, Cf, & $\mathbf{C}$ & \multicolumn{2}{|c|}{ 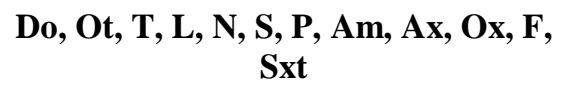 } \\
\hline S. Molade & $\begin{array}{c}\text { Cn, N, L, Ax, Nor, Enr, Sxt, Ct, } \\
\text { C, Levo, Cf }\end{array}$ & $\begin{array}{c}\mathbf{P}, \mathbf{A m}, \mathbf{O x}, \\
\mathbf{O f x}\end{array}$ & \multicolumn{2}{|c|}{ Do, Ot, T, E, S, Ub } \\
\hline S. Anatum & $\mathrm{Cn}, \mathrm{N}, \mathrm{Ct}, \mathrm{C}, \mathrm{Sxt}$, Ofx, Cf & L, Levo & \multicolumn{2}{|c|}{$\begin{array}{c}\text { Do, Ot, T, L, S, P, Am, } \\
\text { Ax, Ox, F, Ub, Nor, Enr, }\end{array}$} \\
\hline S. Newport & $\begin{array}{c}\mathrm{Cn}, \mathrm{N}, \mathrm{Ax}, \mathbf{P}, \mathbf{A m}, \mathrm{Ct}, \mathrm{C}, \mathrm{Cf}, \\
\text { Ofx, Levo }\end{array}$ & Sxt & \multicolumn{2}{|c|}{ Do, Ot, T, L, S , Ox, F, Ub, Nor, Enr } \\
\hline S. Agona & $\mathrm{Cn}, \mathrm{N}, \mathrm{L}, \mathrm{C}, \mathrm{Ct}, \mathrm{Cf}$ & - & \multicolumn{2}{|c|}{$\begin{array}{l}\text { Do, Ot, T, P, Am, Ax, Ox, F, Ub, } \\
\text { Nor, Enr, Sxt, Levo, Ofx, S }\end{array}$} \\
\hline Remark & \multicolumn{4}{|c|}{$\begin{array}{l}\text { - All Salmonella isolates sensitive to }(\mathrm{Cn}, \mathrm{Ct}, \mathrm{Cf}) \\
\text { of Salmonella isolates were resistant to }(\mathrm{Ot}, \mathrm{Do}, \mathrm{T}, \mathrm{Sxt}, \mathrm{Enr}) \text {. }\end{array}$} \\
\hline \multicolumn{5}{|l|}{ *Antibiotics } \\
\hline Penicillin G (P 10ug) & Enrofloxacin (Enr 5ug) & Chloramphen & $\operatorname{col}($ C 30ug) & Tetracycline (T 30ug) \\
\hline Ampicillin (Am 10ug) & Norfloxacin (Nor 10ug ) & Colistinsulph & te $(\mathbf{C t}$ 10ug) & Gentamycin (Cn 10ug) \\
\hline Amoxicillin (Ax 25ug) & Flumeqine (Ub 30ug) & lphamethoxa & ole (Sxt 25ug) & Lincomycin (L 2mcg) \\
\hline Oxacillin (Ox 1ug) & Nitrofurantoin (F 300ug) & Oxytetrayclir & $($ Ot 30 ug ) & Streptomycin (S 10ug) \\
\hline Neomycin (N 30ug) & Doxycycline (Do 30 ug) & Levofloxa & in (Levo) & Ceftiofur (Cf) \\
\hline
\end{tabular}


Table 5: Illustrate the result of sensitivity test for $E$. coli isolates.

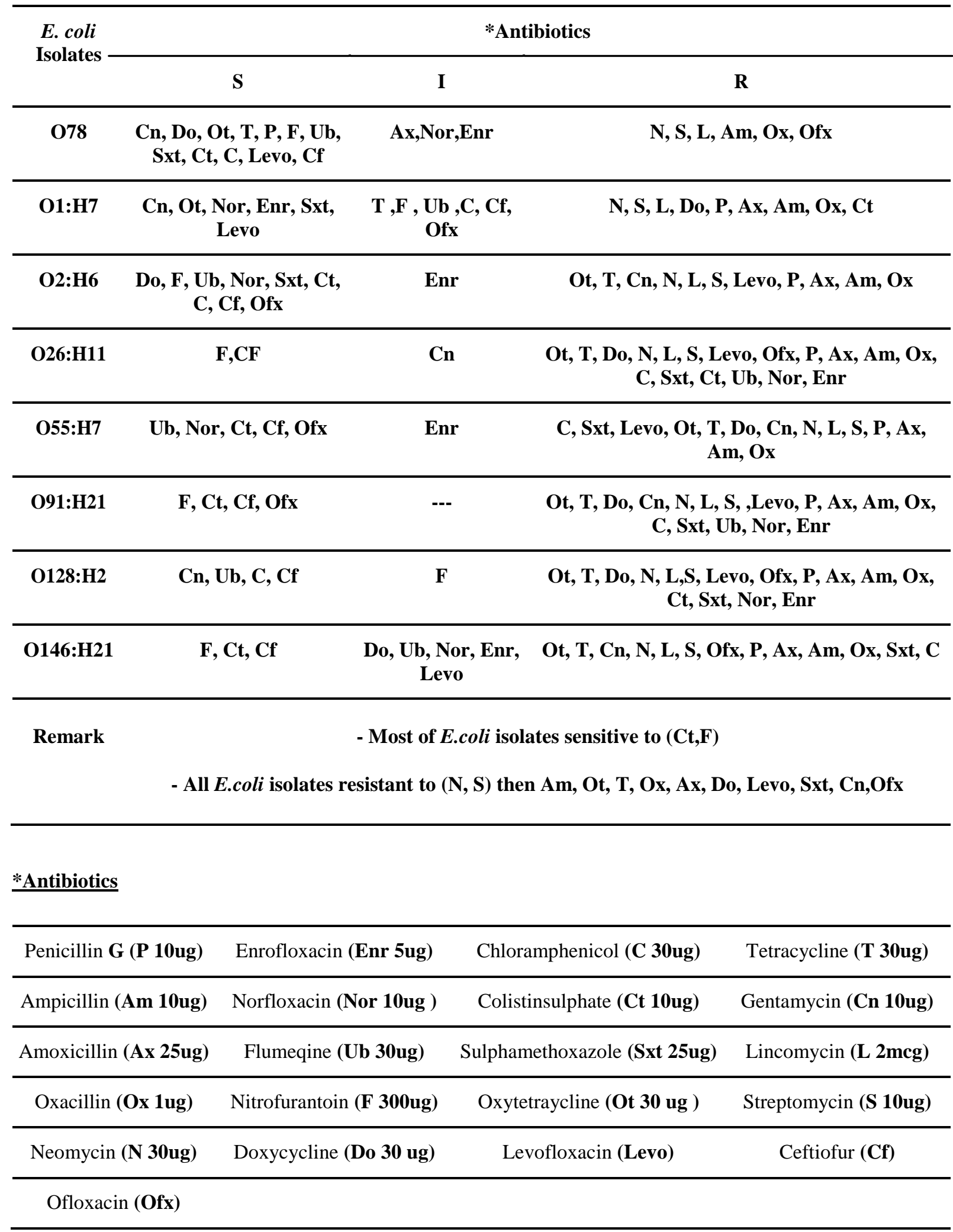




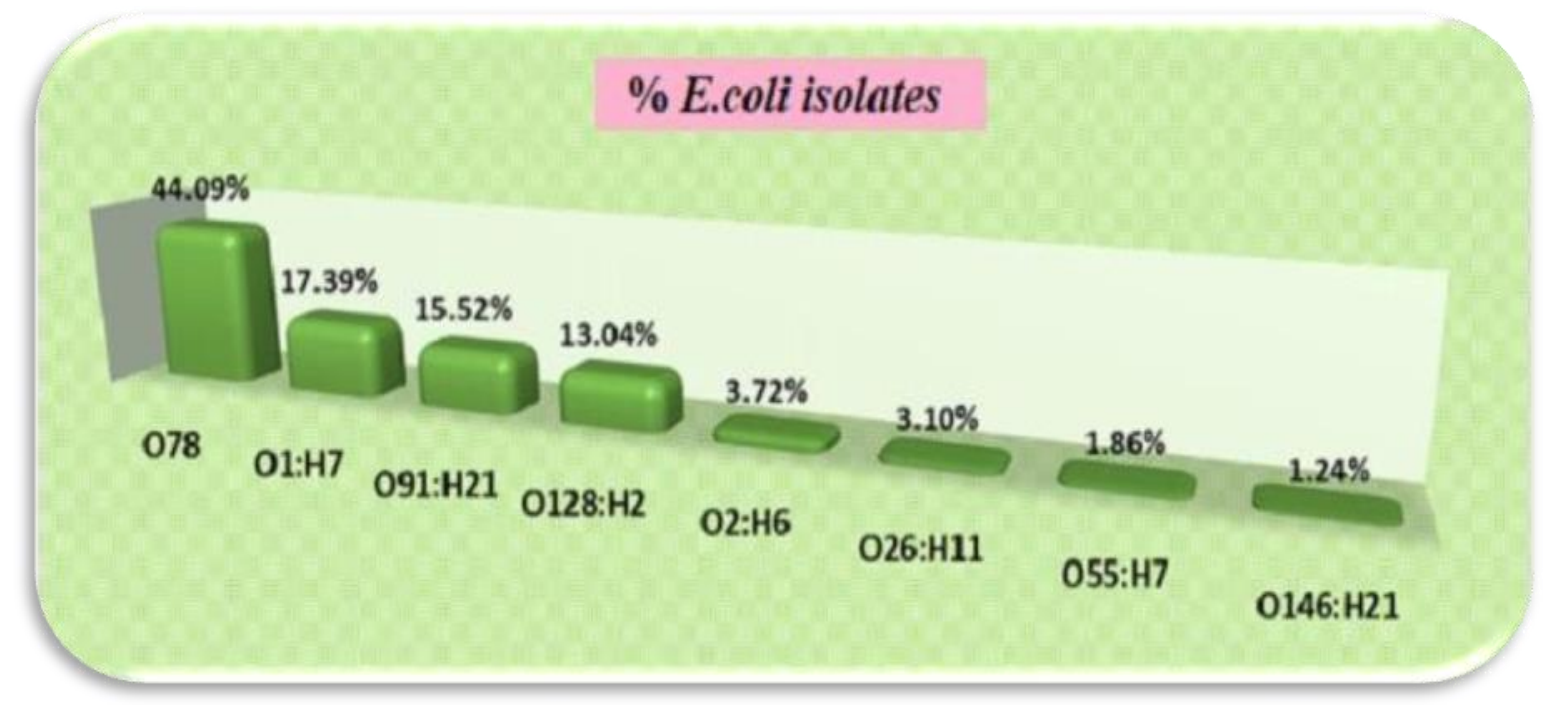

Fig. (1): Shows the common E.coli isolates percentage isolated from broilers.

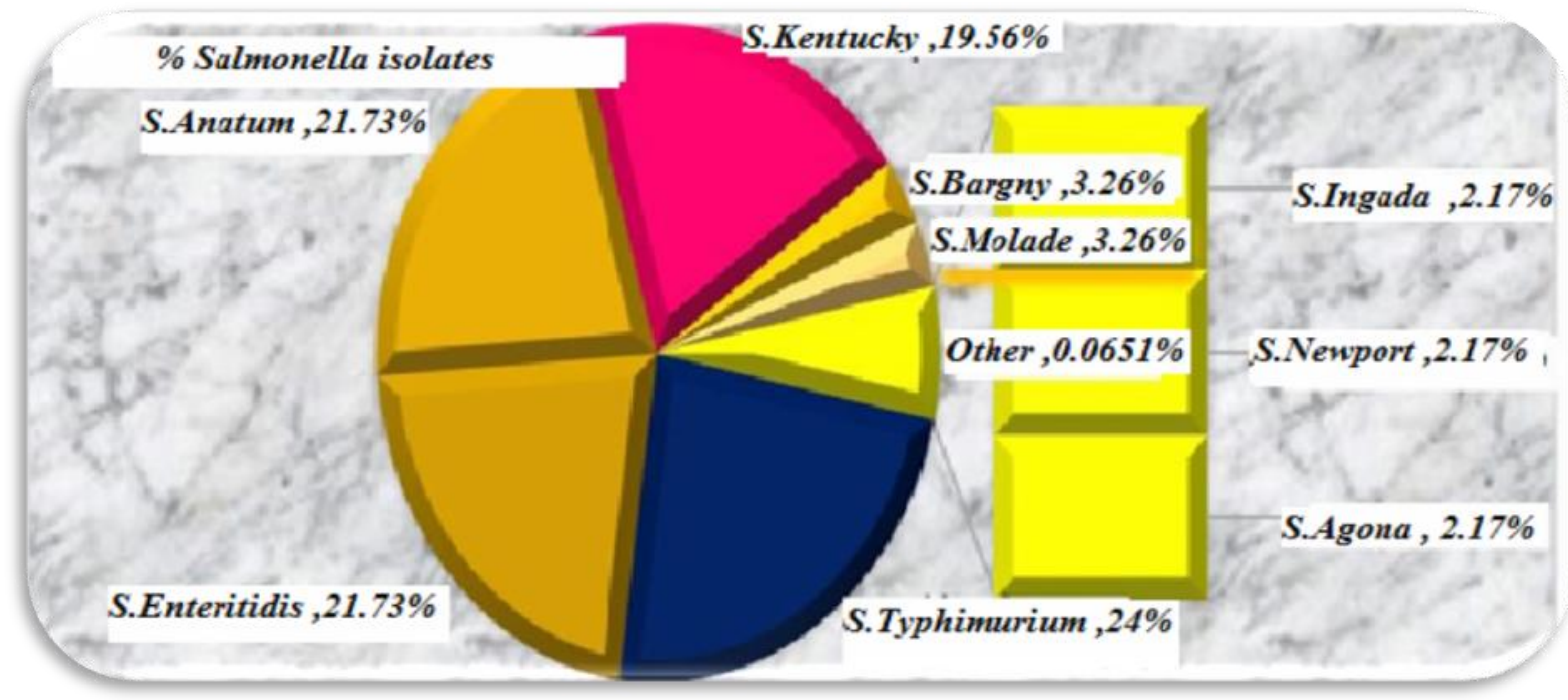

Fig. (2): Shows the common Salmonella isolates percentage isolated from broilers.

\section{DISCUSSION}

The current study showed high prevalence of Colibacillosis and Salmonellosis infections in (Ross, Cup, Hubbard and Sasso) broiler chickens during (2015-2016) at Luxor governorate, E.coli isolates were the predominant $(53.66 \%)$ followed by Salmonella species $(30.66 \%)$ these diseases are considered to be the major bacterial diseases in the poultry industry world-wide and have public health perspective. The same findings have been reported by Sheldon et al. (2006) who said the incidence level of Salmonella was (33\%) isolated from broilers. Also supported by Duane and Donald., (2016) who recorded that from (2013 to 2014) recovery rates of Salmonella significantly decreased from 35\% (39 isolates/112 samples) to $23 \%$ (27/116). And lowest rate was in layer $(27.9 \%)$, the diagnosed diseases included Colibacillosis $(7.4 \%)$, Salmonellosis
$(25.3 \%)$. While the prevalence was high recorded by Yang et al. (2011) who said a high rate of Salmonellosis (52.2\%), in China and also Rahman et al. (2007) who said bacterial diseases Salmonellosis, Colibacillosis of group 2 (growers) were detected in $(55.96 \%)$ and $(11.93 \%)$ respectively.

The present study showed that E.coli was $(53.66 \%)$ from broilers which is agree with the previous studies of (Tapan et al., 2012) detected Colibacillosis from different farms suffered from yolk sac infection one day old till 4week (52.6\%) and (Ahmed et al., 2009) who examined 199 broiler chickens and found 104 $(52.26 \%)$ were infected with E.coli, and also (Ashraf et al., 2015) who showed the incidence of E.coli in on day old living diseased chicks was $(58.3 \%)$ and in freshly dead ones $(55 \%)$ in winter season. Also it was agree with (Heba et al., 2012) who reported that chickens reared in Cairo had the highest rate 
$(58.7 \%)$. The result was gone in parallel with (Fatma et al., 2008) who recorded the isolation of E. coli (60 $\%)$ in broilers chickens. In contrast to our results the prevalence of Colibacillosis was $1.0 \%$ and $0.5 \%$ in 25-30 days old and 31-35 days old broiler as reported by Abdul Matin et al. (2017) as Colibacillosis is prevalent in the study areas which underscore the need of implementation of prevention and control measure against this disease.

Serological identification showed eight serotypes of E. coli $(\mathrm{O} 78, \quad \mathrm{O} 1: \mathrm{H} 7, \quad \mathrm{O} 91: \mathrm{H} 21,128: \mathrm{H} 2, \mathrm{O} 2: \mathrm{H} 6$, O26:H11, O55:H7, O146:H21) were isolated which agree with (Rahman et al., 2004) who reported avian Colibacillosis was frequently associated with $E$. coli strains of serotypes $\mathrm{O} 78: \mathrm{K} 80, \mathrm{O} 1: \mathrm{K} 1$ and $\mathrm{O} 2: \mathrm{K} 1$ and also agree with (Ashraf et al., 2015) who reported the serogroups of $E$. coli that obtained by serological identification were $(\mathrm{O} 128, \mathrm{O} 78, \mathrm{O} 111, \mathrm{O} 124, \mathrm{O} 55$, O142, O114, O2 and O1).

The most prevalent strains of $E$. coli were $(\mathrm{O} 78)$ with percentage $(44 \%)$ followed by $(\mathrm{O} 1: \mathrm{H} 7, \mathrm{O} 91: \mathrm{H} 21$ and O128:H2) with percentages $(17.39 \%),(15.52 \%)$ and (13\%) respectively, other E.coli serovar their percentage varies from $(1: 3 \%)$. These result was in agreement with (Shaohua et al., 2005) who recorded twenty serotypes were identified, with (O78) being the most common $(12 \%)$. Our results were supported by Heba et al., (2012) who reported the most commonly isolated $\mathrm{O}$ groups in chickens were $(\mathrm{O} 78$, O158,O114,O91,O111,O125,O103,O142,O26, O44, $\mathrm{O} 127$ and $\mathrm{O} 164)$. Also the same finding was reported with (Ashraf et al., 2015) who said that E. coli serotypes had been previously isolated from chicken and newly hatched chicks in Egypt were (O78). On contrary to our results El-Sayed et al. (2015) were identified (O111, O55, O142 and O128). Reem., (2015) isolated (O142, O1, O55, O128 O114 and O124) from broiler.

Nine Salmonella serovars were identified, including ( $S$. Typhimurium, $S$. Enteritidis, $S$. Anatum, $S$. Kentucky, $S$. Molade, $S$. Bargny, $S$. Newport, $S$. Agona and $S$. Ingada) the same finding by (Ahmed $e t$ al., 2016) who said seven serovars of Salmonella were isolated from broiler chickens, including $S$. Typhimurium, which accounted for) $52.94 \%$ (of total Salmonella isolates. Other serotypes isolated $(47.06 \%)$ were $S$. Enteritidis, $S$. Arizona, $S$. Kentucky, $S$. Montevideo, $S$. Birkenhead, and $S$. Virchow.

The predominant serovars identified in our study were $S$. Typhimurium $(24 \%)$ then both of $S$. Enteritidis and $S$. Anatum were $(21.7 \%)$ and serovars as $S$. Kentucky (19.56\%) then both of $S$. Bargny, $S$. Molade were $(3.26 \%)$ and $S$. Newport, $S$. Ingada and $S$. Agona their percentages were $(2.17 \%)$ and this agree with Moussa et al. (2010) reported In Saudi Arabia, S. Enteritidis and $S$. Typhimurium dominated among the recovered Salmonella serovars from chicken $(55.56 \%$ and $22.22 \%$, respectively) but very high $S$. enteritidis percentage compared with the present result but the prevalence was high and also agree with Michele et al. (2005) who reported that there were 961 isolates from chickens, 102 from turkeys, and 178 from and the 5 most common serovars were $S$. Typhimurium (23\%), Heidelberg (13\%), S. Hadar (9\%), S. Kentucky (6\%). The prevalence of Salmonella was very absolutely disagree with Yuka et al. (2003) who recorded the most prevalent serovars were $S$. Hadar, $S$. Infantis. This difference in serotypes of isolated Salmonella might be due to the locality and to the environmental condition of isolation.

In the present study showed the prevalence of $S$. enteritidis was $(21.7 \%)$ isolated from broilers and this agree with (Noori and Alwan., 2016) who identified five serotypes were isolated from broiler including $S$. Infantis $(0.54 \%), S$. Vichow $(0.13 \%), S$. Enteritidis $(0.21 \%), S$. Hato $(0.08 \%), S$. Dublin $(0.05 \%)$.

The prevalence of Salmonella, E. coli isolates in the current study was varied from certain studies, these may be due to differences in sampling way, methods of diagnosis, season of initiation Salmonellosis, Colibacillosis in live birds.

All Salmonella serovars were sensitive to (gentamycin, colistinsulphate and ceftiofur) and also in our results $(66.66 \%)$ isolates were sensitive to neomycin except $S$. Kentucky, $S$. Inganda and $S$. Molade. This results were agree with Gomba et al., (2016) who said all Salmonella isolates were susceptible to ceftiofur, cefoxitin, ceftriaxone, ciprofloxacin, nalidixic acid, gentamicin and also supported by (Lamas et al., 2016) that found sixteen different serotypes were found, with $S$. Typhimurium and $S$. Arizonae were susceptible to cefotaxime, ciprofloxacin, gentamycin and neomycin. The result was disagree with (Diarrassouba et al., 2007) indicated that multiple antibiotic-resistant commensal E. coli and Salmonella strains be found on commercial broiler chicken farms and among the 27 amoxicillin andceftiofur.

In the present study the most of Salmonella isolates were resistant to (oxytetracycline, doxycycline, tetracycline then enrofloxacin, sulphamethoxazole) this agree with (Lamas et al., 2016) who said the highest level of resistance was to sulfamethoxazole $(40.29 \%)$, doxycycline $(17.91 \%)$, and nalidixic acid (17.91\%) in Salmonella spp. Also supported by (Moussa et al., 2014) who observed in 33 (58.9\%) of the Salmonella Kentucky isolates; 2 of these isolates were also resistant to chloramphenicol, streptomycin, sulphamethoxazole and tetracycline. 
The majority of $E$. coli isolates $(87.5 \%)$ were sensitive to ceftiofur, $(62 \%)$ of isolates were sensitive to colistinsulphate, nitrofurantoin and $(50 \%)$ were sensitive to flumequine. The results were agree with (Wang et al., 2008) who said cefitiofur should be given by water to treat Colibacillosis in chickens, the suitable dosage was $100 \mathrm{mg} / \mathrm{L}$ and nearly similar to that obtained by Al-khalaf et al. (2009) who said $E$. coli isolates were highly sensitive to enrofloxacin and colistinsulphate.

All E. coli strains were resistant to neomycin and streptomycin, $(87 \%)$ of isolated $E$. coli found resistance for ampicillin, (75\%) of isolates gave resistance for oxacillin, amoxicillin, oxytetracycline and tetracycline, $(62 \%)$ of isolates were resistant for sulphamethoxazole, doxycycline and levofloxacin, $(50 \%)$ of isolates resistant for gentamycin and ofloxacin. The results were nearly similar to that obtained by (Abdul Matin et al., 2017) who said the rate of $E$. coli resistance to ampicillin $(92.7 \%)$, tetracycline $(73.1 \%)$, streptomycin $(80.8 \%)$ and neomycin (76.9\%) and agree with (Mamza et al., 2010:, Ismail et al., 2014) who reported E. coli isolates from the tissues of apparently healthy and sick chickens showed resistance to ampicillin $(66.7 \%)$, tetracycline $(63.3 \%)$. The obtained result was agree with Fatma et al. (2008) who recorded $100 \%$ E. coli isolates were resistant to amoxicillin, tetracycline, oxytetracycline, and ampicillin. As well as agree with (Moon et al., 2011) who studied the actual frequency of antimicrobial resistance in fecal Escherichia coli isolated from. One hundred and nine E.coli isolates were higher resistant to ampicillin $(68.8 \%)$ streptomycin $(60.6 \%)$, ciprofloxacin $(65.1 \%)$, and tetracycline $(96.3 \%)$ and disagree with (Obeng et al., 2012) who recorded E. coli isolates from healthy commercial and free-range chickens in Australia were resistant to ampicillin (26.7\%), streptomycin (10.8\%) and tetracycline (40.6\%).

\section{CONCLUSION}

Detection of multidrug resistant Salmonella and E coli isolated from broiler chickens were recorded in this study these resistance may be due to the miss use of antimicrobial in poultry farm as well as the abuse of the drugs, the administration of antimicrobial drugs should be used according to sensitivity test on isolated organism. The use of the drug should be in recommended dose, time and route of administration.

\section{ACKNOWLEDGEMENTS}

First of all, my prayerful thanks go to "ALLAH" for everything, bestowed on me during my life.

I would like to express my deepest gratitude and appreciation to Dr/ Marwa Abdou for her support and assistance to me in the practical part of research. The support and encouragement received from all my colleagues at RLQP- Luxor branch. Finally, I dedicate this small piece of work to my dearest parents, husband, sisters and sons who always valued education above everything else. Thank You!

\section{REFERENCE}

Abdul Matin, M.D.; Ariful, I. and Minara, M.K. (2017): Prevalence of colibacillosis in chickens in greater Mymensingh district of Bangladesh Md. Veterinary World, 10(1): 29-33.

Ahmed, M.S.; Sarker, A. and Rahman, M.M. (2009): prevalence of infectious diseases of broiler chickens in Gazipur district. Bangladesh Journal of Veterinary Medicine, 7(2): 326331.

Ahmed, M.A.; Adel, A.M.; Marwa, I.A.E.H. and Mona, M.E.A. (2016): Virulence genotypes of clinical Salmonella Serovars from broilers in Egypt. J Infect Dev Ctries 2016; 10(4): 337346.

Al-khalaf, A.N.; Akeila, M.A.; Al-Dubaib, M.A.; Azzam, A.H.; El-Shafey, A.A. and Draz, A.A. (2009): Bacterial Contamination of Hatcheries. Journal of Agricultural and Veterinary Sciences, Qassim University, 2(2): 67-76.

Amagliani, G.; Brandi, G. and Schiavano, G.F. (2012): Incidence and role of Salmonella in seafood safety. Food Research International 45, 780-788.

Ashraf, A.A.E.T.; Samir, A.A.E.A.; Ebtisam, M.M. and Doaa, A.E.M. (2015): Prevalence of E. coli in broiler chickens in winter and summer seasons by application of PCR with its antibiogram pattern. BVMJ-29(2):119-128.

Brenner, F.W.; Villar, R.G.; Angulo, F.J.; Tauxe, R. and Swaminathan, B. (2000): Salmonella Nomenclature. J. Clin Microbiol. 38(7):24652467.

Chansiripornchai, N. (2009): Comparative efficacy of enrofloxacin and oxytetracycline by different administration methods in broilers after experimental infection with avian pathogenic Escherichia coli. Thai. J. Vet. Med., 39(3):231-236.

Charles, O.A.O. and Takayuki, K. (2010): Salmonella enteric serovar Enteritidis, National Agriculture and Food Research Organization (Tsukuba, Ibaraki 305-0856, Japan) JARQ 44(1): 7 - 16.

Chart, H.; Smith, H.R.; La Ragione, R.M. and Wood ward, M.J. (2000): An investigation into the pathogenic properties of Escherichia coli strains BLR, BL21, DH5 $\alpha$, and EQ1. J. Appl. Microbiol. 89, 1048-1058.

CLSI (2008): Performance standards for antimicrobial disk and dilution susceptibility 
tests for bacteria isolated from animals. Approved standard, 3rd ed., M31-A3. Clinical and Laboratory Standards Institute, Wayne, PA.

De Carli, S.; Ikuta, N.; Lehmann, F.K.; Da Silveira, V.P.; De Melo Predebon, G.; Fonseca, A.S. and Lunge, V.R. (2015): Virulence gene content in Escherichia coli isolates from poultry flocks with clinical signs of colibacillosis in Brazil. Poult. Sci., 94: 26352640.

Diarrassouba, F.; Diarra, M.S.; Bach, S.; Delaquis, P.; Pritchard, J.; Topp, E. and Skura, B. (2007): Antibiotic resistance and virulence genes in commensal Escherichia coli and Salmonella Isolates from commercial broiler chicken farms. Journal of Food Protection®, 6(12): 1316-1316-1327.

Duane, E.O. and Donald, D.B. (2016): Proceedings of the Sixty- Fifth Western poultry disease conference. April 24-27, 2016 Vancouver, BC, Canada.

El-sayed, M.E.; Shabana, I.I.; Esawy, A.M. and Rashed, A.M. (2015): Detection of VirulenceAssociated Genes of Avian Pathogenic Escherichia coli (APEC) Isolated from Broilers. J. Genetics. 1(1): 004.

Fatma, M.Y.; Mona, A.A. and Dalia, H.M. (2008): Clinical, Pathological and Bacteriological Investigations on Air Sacculitis in Chickens in Ismailia Province (Egypt). Journal of Agricultural and Veterinary Sciences, Qassim University, 1(2): 71-79.

Gamal, Y.; Amal, A. and Nada, M. (2017): Phenotypic and genotypic characterization of antimicrobial susceptibility of avian pathogenic Escherichia coli isolated from broiler chickens. Vet World. 2017 Oct; 10(10): 1167-1172.

Gomba, A.; Chidamba, L. and Korsten, L. (2016): Foodborne Pathogens and Disease. ahead of print.doi:10.1089/fpd.2016.2120. Antimicrobial Resistance Profiles of Salmonellaspp.

Haider, M.G.; Hossain, M.G.; Hossain, M.S.; Chowdhury, E.H.; Das, P.M. and Hossain, M.M. (2004): Isolation and Characterization of Enterobacteria Associated with Health and Disease in Sonali Chickens. Bangladesh Journal of Veterinary Medicine 2 (1):15-21.

Heba, R.; Soad, A. El-Aziz. and Mohamed, R. (2012): Incidence of $E$. coli in chickens and ducks in different governorates in Egypt, $1^{\text {st }}$ Conf. of An. Health Res Harvey J, Patterson JT, Gibbs PA. Enterotoxigenicity of Staphylococcus aureus strains isolated from poultry: Raw poultry carcases as a potential food-poisoning hazard. J Appl Bacteriol. 1982; 52:251-258., Inst. Assoc., December . pp. 420 - 426.

Holmes, B.; Willcox, W.R. and Lapage, S.P. (1978): Identification of Enterobacteriaceae by the API 20E system. Journal of Clinical
Pathology, 1978, 31:22-30.

Ismail, A.E.R.; Hala, S.H.S.; Soad, A.E.A.A. and Marwa, A.Y.A.S. (2014): Frequency of some virulence associated genes among multidrugresistant Escherichia coli isolated from septicemic broiler chicken. International Journal of Advanced Research (2014), 2(12): 867-874.

Johnston, A. (2007): Current disease of ducks and their control. Poult. Int., 46: 24-29.

Kauffman, G. (1974): Kauffmann white scheme. J. Acta. Path. Microbiol. Sci., 61:385.

Kok, T.; Worswich, D. and Gowans, E. (1996): Some serological techniques for microbial and viral infections. In Practical Medical Microbiology (Collee, J.; Fraser, A.; Marmion, B. and Simmons, A., eds.), 14th ed., Edinburgh, Churchill Livingstone, UK.

Lamas, A.I.C.; Fernandez-No, J.M.; Miranda, B.; Vázquez, A.; Cepeda. and Franco, C.M. (2016): Prevalence, molecular characterization and antimicrobial resistance of Salmonella serovars isolated from northwestern Spanish broiler flocks (20112015) Poultry Science (September 2016) 95 (9): 2097-2105 first published online May 3, 2016 doi:10.3382/ ps/pew150. Poultry Science (2016) doi: 10.3382/ps/pew150v1.

Mamza, S.A.; Egwu, G.O. and Mshelia, G.D. (2010): Antibiotic susceptibility patterns of betalactamase-producing Escherichia coli and Staphylococcus aureus isolated from chickens in Maiduguri (Arid zone), Nigeria. Vet. Arhiv 80, 283-297.

Michele, T.G.S.; Wayne, M.S.; Gerarda, A.D. and Andrijana, R. (2005): A temporal study of Salmonella serovars in animals in Alberta between 1990 and 2001, Can J. Vet. Res. 69(2): 88-99.

Moon, H.J.; Jae, K.C.; IDong, M.; Gil-Jae, C. and Young, J.L. (2011): Antimicrobial Resistance and Resistance Gene Determinants of Fecal Escherichia coli Isolated from Chicken. Korea Journal of Animal and Veterinary Advances 10(24): 3308-3311.

Moussa, I.M.; Gassem, M.A.; Al-Doss, A.A.; Mahmoud, W.A.S. and Abdel Mawgood, A.L. (2010): Using molecular techniques for rapid detection of Salmonella serovars in frozen chicken and chicken products collected from Riyadh, Saudi Arabia. Afr J Biotech no 19 : 612-619.

Noori, T.E. and Alwan, M.J. (2016): Isolation and Identification of Zoonotic Bacteria from Poultry Meat. www.ijarbs.com,. Int. J. Adv. Res. Biol. Sci. Vol 3(8): 57-66.

Obeng, A.S.; Rickard, H.; Ndi, O.; Sexton, M. and Barton, M. (2012): Antibiotic resistance, phylogenetic grouping and virulence potential of Escherichia coli isolates from the faeces of intensively farmed and free-range poultry. 
Vet. Microbiol. 154, 305-315.

Quinn, P.J.; Markey, B.K.; Carter, M.E.; Donnelly, W.J.C. and Leonard, F.C. (2002): Veterinary microbiology and microbial diseases. $1^{\text {st }}$ Iowa State University Press, Ames, Iowa, USA. 536 pp. ISBN 0-632-05525-1.

Rahman, M.; Rahman, A.Z. and Islam, M.S. (2007): Bacterial diseases of poultry prevailing in Bangladesh. Journal of Poultry Science, 1(1): 1-6.

Reem, M.S. (2015): Molecular detection of antibiotics resistant genes among E.coliisolated from diseased chickens. Ph.D. Thesis, Fac. Vet. Med., Benha. Univ.

Sheldon, B.W.; Li, X.; Payne, J.B.; Santos, F.B.O. and Anderson, K.E. (2006): Surveillance of Salmonella populations, prevalence and serotype diversity in layer feces as a function of production cycle and molting. EPC 2006 12th European Poultry Conference, Verona, Italy, 10-14 September, 2006. 2006. paper 293. 11 ref.

Solà-Ginés, M.; Cameron-Veas, K.; Badiola, I.; Dolz, R.; Majó, N.; Dahbi, G.; Viso, S.; Mora, A.; Blanco, J.; PiedraCarrasco, N.; GonzálezLópez, J.J. and Migura-Garcia, L. (2012): Diversity of multi-drug resistant avian pathogenic Escherichia coli (APEC) causing outbreaks of colibacillosis in broilers during 2012 in Spain. PLoS One, 10(11): e0143191. DOI: 10.1371/journal.pone.0143191.

Tapan, K.S.; Lakshman, S.; Laxmi, N.; Sarangi, S.; Kumar, P. and Hemant, K.P. (2012): Prevalence, Isolation, Characterization and Antibiogram Study of Pathogenic Escherichia coli from Different Poultry Farms of Odisha. Journal of Advanced Veterinary Research 2:169-17.

Thung, T.Y.; Mahyudin, N.A.; Basri, D.F.; Wan, C.W. J.; Mohamed, R.; Nakaguchi, Y.; Nishibuchi, M. and Radu, S. (2016): Prevalence and antibiotic resistance of Salmonella Enteritidis and Salmonella Typhimurium in raw chicken meat at retail markets in Malaysia. Poultry Science, Volume 95, Issue 8, 1 August 2016, Pages 1888-1893.

Wang, C.; Lihui, Y.; Jie, L.; Sun, Y.; Su, Y. and Liu, M. (2008): Antimicrobial Activity in vitro and Therapeutic Effect of Ceftiofur on Experimentally Infected Chickens with Colibacillosis, China Poultry 2008-15, Cate Gory Index: S858.31.

Yang, B.; Xi, M.; Wang, X.; Cui, S.; Yue, T.; Hao, H.; Wang, Y.; Cui, Y.; Alali, W.Q.; Meng, J.; Walls, I.; Wong, D.M. and Doyle, M.P. (2011): Prevalence of Salmonella on raw poultry at retail markets in China. J Food Prot 74:1724-1728.

Yuka, M.; Rishou, Y.; Shuujirou, U.; Tadashi, T.; Koichi, O. and Toshiyuki, M. (2003): Salmonella enterica subsp. Entericaserovar Agona infections in commercial pheasant flocks. Livestock Hygiene Service Center, Tosa, 781-1102, Kochi, Livestock Experiment Station, Sakawa, 789-1233, Kochi Division of Livestock and Poultry, Department of Agriculture, Forestry and Fisheries, Kochi Prefectural Government, 780-0850, Kochi Version of record first published: 12 Jul 2010. Avian Pathology, 32: 4, 355-359.

\section{قابلية مضادات الميكرويات لسلالات السالمونيلا والايشيريثيا كولاى المعزولة من دجاج التسمين بمحافظة الأقصر}

\section{صفاء زكريا قاسم ، أحمد إبراهيم ، نبيلة عثمان ، سعاد ناصف}

E-mail: s_z_11@yahoo.com
Assiut University web-site: www.aun.edu.eg

تعتبر البكتبريا المسببه للسالمونيلا والايثيريشيا كولاى من الامراض التى تؤثر اقتصاديا على الانتاج الداجنى في مصر كما انها

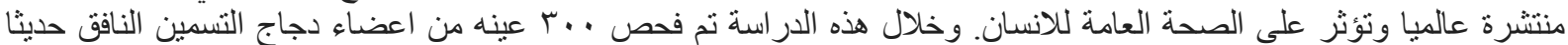

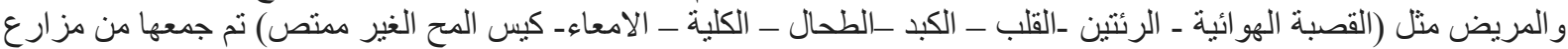

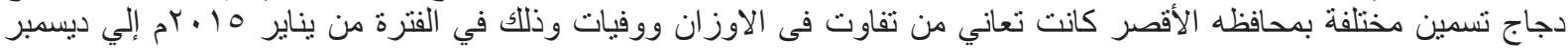

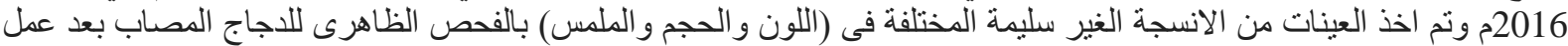

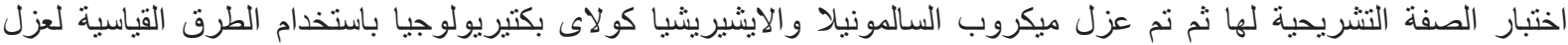

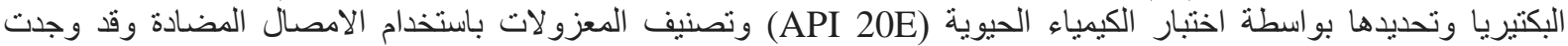

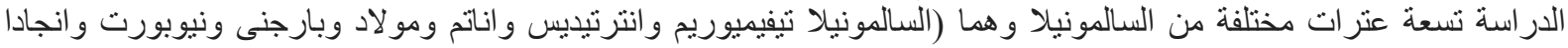

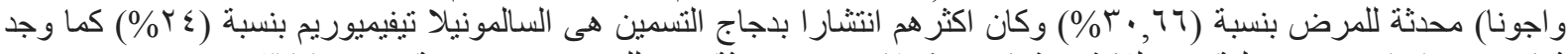
ثمانى

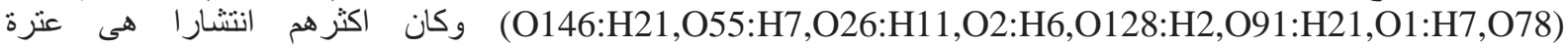

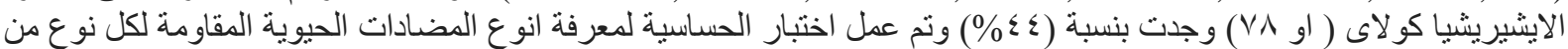

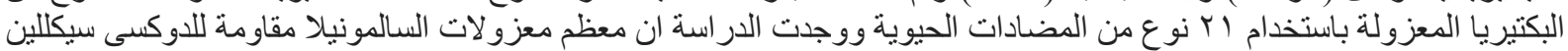

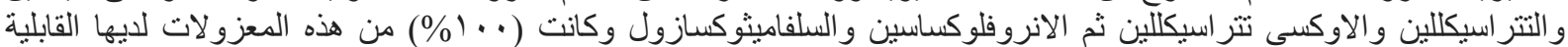
للمضادات الاتية الجنتاميسين و الكولستين سالفات و السيفتى فيور بينما وجدت ( للسيفتى فيور وكذللك ( . 1\%) من الايثيريشيا كو لاى مقاومة للنيو مايسين و الاستريبتو مايسين. 